\title{
The effect of presence and power in the pastoral supervisory relationship
}

\author{
Bill Mullally
}

The Revd Bill Mullally serves in the Methodist Church in Ireland and is currently President of the Methodist Church in Ireland. His doctoral research explores supervision in ministry, and he has been appointed as a Reflective Partner to the Methodist Church in Britain to research the implementation and outcomes of their supervision process.

mullally1@gmail.com

Cork, Ireland

This article addresses the important elements of presence and power in the pastoral supervisory relationship. It is based on qualitative research, which used a questionnaire methodology with six Methodist ministers, all of whom had taken part in group pastoral supervision for a period of two years. The aim of this research was to gain insight into their experience of the supervisory process. The article explores how an open, authentic and trusting environment can be created within the pastoral supervisory relationship that has regenerative and healing potential, whereby ministers will be better able to face the challenges of ministry. It contends there is a need for well-qualified, skilled and spiritually sensitive supervisory support for ministers. Such pastoral supervisors will understand the dynamics of power and presence to create a sacred space for ministers to 'come apart and reflect a while'. This covenant relationship creates transformational possibilities for those who commit to the journey.

GROUP SUPERVISION • PASTORAL SUPERVISION • PRESENCE • POWER • SUPERVISORY RELATIONSHIP • SUPPORT FOR MINISTERS • PASTORAL SUPPORT • MINISTER BURNOUT 


\section{Introduction}

Paul Vitello reports in the New York Times:

Members of the clergy now suffer from obesity, hypertension and depression at rates higher than most Americans. In the last decade, their use of antidepressants has risen, while their life expectancy has fallen. Many would change jobs if they could. ${ }^{1}$

While this is an American report I believe a similar pattern is emerging in the United Kingdom. Daniel Sherman, from PastorBurnout.com, says:

Those in ministry feel they don't know where to turn when they have a family or personal conflict or issue. They feel unable to meet the needs of the job. They report severe stress causing anguish, worry, bewilderment, anger, depression, fear, and alienation. They would leave the ministry if they had somewhere else to go or some other vocation they could do. Congregations don't know or understand the nature of pastoral stress. ${ }^{2}$

My own personal journey as a minister, now in the Methodist Church in Ireland, holding responsibilities at local, national and international level, has convinced me that pastoral supervision can be a key instrument in developing greater resilience in ministers to effectively deal with the tasks and challenges they face.

In order to give meaning to the term 'supervision', I offer a well-captured explanation by Hawkins and Shohet followed by a definition from the Association of Pastoral Supervisors and Educators:

Supervision is a joint endeavour in which a practitioner, with the help of a supervisor, attends to their clients, themselves as part of their client practitioner relationships and the wider systemic context, and by so doing improves the quality of their work, transforms their client relationships, continuously develops themselves, their practice and the wider profession. ${ }^{3}$

Pastoral supervision offers pastoral workers a retreat from the demands of their responsibilities where resourcing and reflection 
can occur within a regular, planned, intentional, boundaried space. It provides a safe place where pastoral workers can be supported and challenged to become the best practitioners they can be for the benefit of the people they serve. ${ }^{4}$

In this article, I explore two key issues that influence and affect attaining a supervisory space that is both sacred and safe for those who participate in pastoral supervision. As I have reviewed, engaged and reflected on the discourses within the literature concerning the purpose and process of pastoral supervision, I found little is said about presence and even less about the dynamics of power. In my experience, these crucial elements of presence and power within the supervisory relationship are not often reflected on, acknowledged or openly addressed, but they exist and influence the individuals involved in both a conscious and a subconscious way. The existence of these dynamics can affect the processes of communication, vulnerability and transparency, which in turn can determine the depth of the trusting relationship and consequently affect the supervisory experience and benefit. This article investigates how a deeper knowledge of these two elements within pastoral supervision could enhance and develop the supervisory experience as a transformational encounter for those involved, which will better support the ministers concerned and equip them to face the challenges in the Church today.

This article reveals the qualitative data from the findings of a research questionnaire, which was compiled and distributed for the purpose of exploring, recording, analysing and drawing conclusions about the significance of presence and power within the supervisory relationship. Six Methodist ministers, who each took part in one of two supervision groups, and who had not previously experienced pastoral supervision, took part in this empirical study. After participating in supervision for a period of two years, they were asked to complete the questionnaire. They were asked how the elements of presence and power might enhance and develop the supervisory experience, or distract and obstruct meaningful pastoral supervision. The findings of the questionnaire were collated to determine what factors of presence and power might assist in making pastoral supervision productive, safe and desirable.

The author guidelines of the journal Reflective Practice provide a framework to promote critical reflection on formation and supervision in ministry in various contexts and from diverse Christian traditions. The guidelines state: 
Good practice relies on ongoing reflection. The capacity for critical self-reflection is an essential dimension of any habitus for ministry and religious leadership. Pastoral Supervision is itself a practice that occurs in relationships that encourages such critical reflection in ministry. ${ }^{5}$

I undertook this research as part of my own reflective practice and offer its results for publication in the hope that it will contribute to the reflective development of clergy supervision in other contexts. Having been supervised and having offered supervision myself for a period of almost 40 years, within different contexts, I am convinced that a central and crucial element of effective supervision is the supervisory relationship. Rogers states that a deep human encounter lies at the centre of all helping relationships, commenting, 'If I can provide a certain type of relationship, the other person will discover within himself the capacity to use that relationship for growth, and change and personal development will occur. ${ }^{6}$ I have found that, for some, engagement in supervision presents a scenario of personal exposure and accountability which makes them feel threatened and unable to participate. In my experience of initiating voluntary pastoral supervision groups among clergy there was an unwillingness to engage in supervision by 20 per cent of those invited. This may be for many different reasons, not least trust, confidentiality, cultural identity and personality influences. The perception and use of power, together with the influence of presence, are the two factors further discussed in this article.

My thesis is that supervision is influenced by the sense of safe presence, that is itself influenced by perceived or real power within the dynamics of the supervisory relationship. In order to examine my thesis about the effect of presence and power in the supervisory relationship, I took a practical approach consisting of an empirical study of the topic, using a questionnaire to collect insights from a sample group. The participants were all ordained Methodist ministers from Ireland, who were colleagues who volunteered for group pastoral supervision. The purpose of the questionnaire was to record, analyse and attempt to draw conclusions about the significance of presence and power within the supervisory relationship and what assists to make it productive, safe and desirable. The questions were designed to be open-ended, and were intended to give the participants the opportunity to explore their perceptions of these two elements, without any prejudice or leading. This article had its beginnings in a Doctor of Professional Studies in Practical Theology through 
the Department of Theology and Religious Studies at the University of Chester. As such, the research proposal and ethical permission for the questions and evaluation thereof were monitored through the university. The questions are attached in an appendix.

\section{Pastoral supervision in ministry}

As the term 'supervision' is fraught with confusion and misunderstanding, I commence with a broad overview of the concept and a specific explanation, as it applies to my field of research for this article. If one reflects upon it, supervision is received by us in one form or another throughout our whole lives: parental supervision, educational supervision, work supervision, professional supervision, and so on. Feinberg says that 'the term supervision falls victim to ... death by a thousand qualifications.7 Supervision conjures up the notion of oversight, seniority, greater experience and more responsibility. There is often a connection between supervision and power over a person who is less experienced and in need of monitoring, evaluation and control. There are times when this is necessary or even essential. Pohly comments on this notion: 'Supervision is a term that is loaded with baggage ... It suggests a hierarchy of superiority/inferiority and dredges up threatening associations with the past. ${ }^{\prime}$ Yet supervision, helpfully understood and practised, can have profound effects on those who participate and can lead to life-changing outcomes, both personally and in the workplace.

Carroll says, 'Supervision has been around for over a century and in that time it has developed substantially. ${ }^{9}$ While this may be true within the professional caring industry, in my experience this is not the case in formal pastoral supervision within the Church.

According to Pohly, the theological and biblical roots of supervision are planted in the covenant concept of Hebrew/Christian tradition. ${ }^{10}$ God's covenant with Israel was one of promise and response. God offered life with a condition of accountability:'I will make of you a great nation' (Gen 12:2) and 'you shall keep my covenant' (Gen 17:9).

Accountability and support for the safe and authentic practice of Christian ministry is an essential part of our Christian DNA and is necessary for accountability to God, self and others. There have been several initiatives in launching supervision in the Christian environment generally, and within the 
Methodist Church in Ireland and Britain specifically. As early as 1999, the Methodist Church in Britain was advocating supervisory practice as an essential part of the practice of ordained presbyters.

In 2015, as a result of recommendation 7 of the Courage, Cost and Hope report on the Past Cases Review, it was agreed that'a system of structured supervision for ministers be instituted to address the identified weakness in relation to accountability and support in terms of safe practice.' ${ }^{11}$ This process is currently working through a pilot project.

The Methodist Church in Ireland began supervision training for its superintendent ministers responsible for supervising probation ministers in 2011, which has produced fruitful engagements and normalised the experience of giving and receiving supervision. However, pastoral supervision has not been officially extended to all ordained ministers as yet.

The Association of Pastoral Supervisors and Educators (APSE), founded in 2009, has been particularly proactive in promoting high standards of pastoral supervision. Part of their vision is:

- to provide a system of accreditation for pastoral supervisors and educators in pastoral supervision

- to support initiatives in the training of pastoral supervisors

- to foster groups for the support, accountability and continuing development of pastoral supervisors

- and to encourage conversation among the various traditions and contexts of pastoral supervision and pastoral supervision education. ${ }^{12}$

However, despite these efforts, there is still a failure to adequately support those in ministry, or to create space for processing and resolving issues, at both a personal and an organisational level.

In this article, the supervision context is understood to be pastoral in nature and approached from a Christian viewpoint. Pastoral supervision is defined by the Association of Pastoral Supervisors and Educators as being a

regular, planned, intentional and boundaried space; with relationships characterised by trust, confidentiality, support and openness that gives the supervisees freedom and safety to explore 
the issues arising in their work. It is spiritually and theologically rich work within a framework of understanding in dialogue with the supervisee's worldview and work. It is psychologically informed, contextually sensitive and praxis based. It is a way of growing in vocational identity, pastoral competence, self-awareness, pastoral interpretation, quality of presence, accountability, spiritual/ theological reflection, response to challenge, and mutual learning; and attentive to the issue of fitness to practice. ${ }^{13}$

This definition lays out a helpful structure for a healthy and open pastoral supervisory relationship. I believe, however, the matter of exploring the issues arising in their work' should be consciously taken a step further. As proposed by Miller and Rollnick and Page and Wosket, supervision should create a safe space for internal processing and also be a partnership in which the supervisor and supervisee work together to draw forth the supervisee's own inner knowledge. $^{14}$

This acknowledging of and working with the supervisee's interior knowledge and experience is of particular significance within pastoral supervision, which Holton calls the 'Intentional reflective practice that engenders transformative learning! ${ }^{\prime 1}$ Its aim is

to widen the discussion from a factual base (what is happening) to a meaning-making process that helps us read the facts or make sense of the facts through adopting a spiritual stance of wonder, awe, mystery, stopping, critical reflection, wisdom, contemplation, and stillness. ${ }^{16}$

Thus the term 'pastoral supervision' refers not to supervision specifically for pastors or ministers, but rather the term refers to the pastoral approach within the supervision. Following the pastoral example of Christ, called the Good Shepherd (Jn 10:11), pastoral supervision implies an encounter that practises a caring attitude and a peaceful presence, necessitating a careful use of power to create a safe space and spiritual openness. Pohly affirms this when he speaks of 'Christ's own oversight and shepherding.' ${ }^{17}$ 


\section{Presence in the pastoral supervisory relationship}

Presence can mean different things to different people. While the comments included here were given by the respondents who took part in group supervision, it is recognised that many of the aspects mentioned could be transferrable to the context of one-to-one pastoral supervision.

Respondents mentioned that effective supervision occurred when those involved were 'intentionally meeting for a singular purpose' and were 'willing to participate and share'. What is evidenced here is the need for participants in supervision to be clear about the purpose of their meeting.

A key aspect of pastoral supervision, which was appreciated by one respondent, is the presence of others who hold similar understanding of ministry. Even within a comparatively homogenous group of ministers from the same denomination, diversity must be taken into account, including gender, marital status, sexual orientation, age, place of origin, and the individual background and context within which each person was raised.

One respondent also noted that the supervisory dynamic itself takes on its own identity: 'The relationship can develop its own "personality" and can proceed at its own pace according to the needs and inclinations of those involved.' A similar comment described 'a kind of "energy transfer" between people who are keenly in tune with one another'.

The respondents indicated the benefits of pastoral supervision, understood through the lens of 'presence'. I have chosen to quote their actual words, since these give some sense of the significance, depth and multifaceted dimensions of their understanding of the supervision encounter:

- 'The presence of each other - to give encouragement and accountability.'

- 'This heightened alertness embraces the relationship with the other members present and enables me to focus more intently on the role and value in this encounter. There is also a sense in which the words of the other people assume a stronger resonance as they come under closer and more focused scrutiny.

- 'We were there to focus on each other, and nothing else ... through the gentle, sensitive probing of others, these issues were clarified, sometimes simplified, sometimes made easier to address for the person in question. The "presence" of others allows different perspectives to be considered. 
"Presence" can be a two-way process - it is as we listen to others, issues in our lives can become clearer.'

Thompson captures something of this dynamic experience when he says that 'a rigorous exploration is undertaken to discover how a theological perspective may illuminate, interrogate and suggest alternative ways of acting, in a process that also sheds new light on that theological perspective.' ${ }^{18}$

Respondents' comments also indicated that they experienced their peers in the group as 'there for them', and that their presence communicated 'love, fellowship and support'. This is central to a meaningful supervisory experience in which one can hear oneself think: 'Each other person there with a sensitivity to one another enables it to be an easy environment in which to speak.' This quality of presence within pastoral supervision creates a thinking environment that can be very different to that which is common in our culture, or even within many church interactions. Our Western culture is one that tends to emphasise:'Think the way others are thinking. Think to impress. Think to avoid ridicule. Think to get a promotion. Think to out-manoeuvre. ${ }^{19}$ Even if the 'thinking' is not as obviously a 'survival of the fittest' mentality, as described by Kline, ministerial inclination can often be to 'rescue' the other. In contrast, the pastoral supervisory experience, as mentioned in these quotes by supervisees, is a different and more helpful way of encountering one another: 'Our desire, with the best intentions, to provide a solution to an issue can blind us to the fact that a colleague needs help and space to find his/her own solution.'This is described by one respondent as 'having the "presence" of mind to resist offering what one thinks is the answer but more importantly helping them to find the answer in themselves; often with pertinent questions'.

The value of pertinent questions, identified by the respondent, is amplified by Davys and Beddoe, who comment, 'Supervision is about asking questions which in turn lead to more questions. This develops learning, which is not necessarily about answers. ${ }^{20}$ This process relies upon the awareness and listening skills of the group members, as expressed by one respondent: 'Presence ... takes effort, particularly to listen, as we're used to waiting for the gap in conversation and giving our opinions.'

Pastoral supervision is an opportunity for the participants to develop the practice of becoming more consciously present to themselves, to their thoughts, their emotions and physical responses, and to their own inner experience, using all their senses - listening, sight, and so on, to engage with the other. Silsbee defines presence as a 'state of awareness, in the moment, 
characterized by the felt experience of timelessness, connectedness and a larger truth.21 This heightened attention benefits not only the individual but also the group process, as one respondent commented, 'the more present the person, the more they take in'.

The responses to a question about the concept of being present to oneself and others were particularly rich, and are quoted verbatim here:

- 'Being "fully present" the giving of time, genuine attention, thought, prayer etc - in a word, love.'

- $\quad$ 'Being present in a physical sense, aware of where I am.'

- $\quad$ 'Being intentional in laying aside of all other distractions and applying concentration.'

- 'Being engaged - your body can be there but mind absent - and fully "there". Being present ... means listening, being willing to participate and share.'

- $\quad$ 'Being present means giving oneself wholly (as wholly as is possible.)'

- 'Being aware of the importance of this particular moment in time ... heightened alertness to this context.'

One response indicated that choosing to be fully present can deepen empathy: 'We try to imagine how we would feel and how we would act if we found ourselves in that situation. The benefit to self of the pastoral supervisory process was described by another respondent as a 'sense of assurance, wellbeing and deep down sense of peace.' This empowering experience, which is both exemplified and facilitated by a competent supervisor, is expressed in one respondent's metaphor:'We should, perhaps, think of ourselves as midwives we assist others to give birth to solutions!'

This metaphor gives some indication of the process of pastoral supervision, where the answers lie within oneself, and other group members assist in bringing these awarenesses, clarifications and alternative perspectives into consciousness.

Another metaphor that may be helpful in comprehending the experience of pastoral supervision is that of the journey to the promised land, which Brueggemann termed an 'ongoing pilgrimage.22 This was a journey experienced in company with others. In the words of one respondent, 'The 
presence of others enables us to learn from the perspectives of each other. It helps me to appreciate that whatever I am going through is not necessarily as uncommon as I might otherwise have perceived it to be.' In other words, pastoral supervision is an opportunity to explore territory that one has not explored before, to travel intimately alongside others sharing not only the conversation and the nurture but also the beauty, the silences, the challenges and the discomforts, while all the time having a sense of a distant destination that is not yet in sight.

While the pastoral supervision group journeys as a community, there is also an individual response. Such individual responses are also recorded throughout Judeo-Christian history. Each story of the Bible is also 'an account of human response. ${ }^{23}$ One respondent commented upon this human struggle to respond: 'Sometimes the Power of God's Spirit confirms ... [the] decision you should take, and this realisation can be unsettling and uncomfortable.'

This brings us to another aspect of presence in the pastoral encounter: the presence of God. It is to be noted that a number of different expressions of Divine Presence were given by members of the two groups of clergy participating in this research, when asked to articulate their understanding of presence. Whereas one respondent suggested 'something more akin to energy and enablement', others referred very directly to a personal presence, using the terms 'Jesus,', 'Christ', 'God' and 'Spirit'. Research respondents indicated the intention of the group was to 'meet together in Jesus' name' with 'the Presence of Christ in their midst'. There was also an acknowledgement of Jesus as 'the Lord of the Church' and that we 'meet as his church and sit under his ultimate authority, in all we say and do'. In one group the lighting of a candle was offered as a symbol,'indicating and inviting the Presence of God. It was expected from that moment on our minds were being guided by God, whose desire for us all is peace.' Several respondents expressed their understanding of the perceived purpose of this Divine Presence: 'to guide, influence, encourage, reassure and stimulate'; 'help shape the discussion and the spirit in which it is conducted'; 'illuminate things and brings clarity, leading to appropriate responses'; and be a Presence, 'creating feelings and emotions, influencing opinions and decisions taken'. Others referred to the benefit of this Presence as a 'sense of assurance, well-being and a deep-down sense of peace that God is ultimately in control', and 'God is very present in the silent reflection and spaces, or pauses, which are integral to meaningful pastoral supervision'. This Presence also 'brings the right perspective and order to the gathering'. 
As observed by one respondent, 'The Presence of God is vital to the dynamic of supervision.'The experience of Divine Presence within the pastoral supervisory relationship is underpinned by the truth and promise of the 'one God and Father of all, who is over all and through all and in all' (Eph 4:6). God's presence is not only found in the mystical and invisible but also in the way in which the group members are present to each other and witness each other's experience. A parallel experience can be seen in Jesus' encouragement to his disciples: 'Let us go off by ourselves to some place where we will be alone and you can rest a while' (Mk 6:31). He models the need not only for acts of kindness within community but also for an opportunity to draw apart to reflect with one another and to be still to hear God.

What is essential, despite the different terminology used to express the sense of Divine Presence, is the way group members encounter one another as they share their own 'history', as articulated by Ballard: 'God is present "by, with and under" the historical reality of the creature. History itself can thus be sacramental, the place of meeting with the divine. ${ }^{24}$ There is in pastoral supervision the opportunity to see and reflect the compassion of Jesus. Edward Schillebeeckx reminds us that 'human encounter with Jesus is, therefore, the sacrament of encounter with God'.25

When pastoral supervision is an encounter with God, through God, in God and one another in the spirit of love, God is at work. The Apostle John affirms, 'No one has ever seen God. Yet, if we love one another, God remains in us, and his love is brought to perfection in us' (1 Jn 4:12). God's love in us becomes the transformational agent for the other's growth and well-being.

As already discussed, the pastoral supervisory process creates a sense of 'pilgrimage', and at the personal level there may be a parallel with Christ's journey to crucifixion, resurrection and ascension. This can be understood as a need to 'die' to old habits and mindsets in order to enable a new and different way of being. This is an ongoing journey that will take a lifetime to accomplish.

All bring our own expertise and experiences, our prejudices and ignorance to the process ... and need to work through them, perhaps unlearn them, so that they do not get in the way and suppress the voice of the Spirit. We also have to be open to learn new things about ourselves, about God, about the world, that can either be exciting or fascinating or, perhaps, fearsome and difficult. It is necessary to work through them and come out the other side. ${ }^{26}$ 
The pastoral supervision journey can provide fellow pilgrims who offer helpful support and accompaniment during the joys and challenges of ministry.

Despite the many benefits mentioned above, it is important to note that there may be concerns about how the psychological safety of the supervision experience could be compromised if boundaries are crossed. Depending on the nature of the relationship between the people involved, it can sometimes be uncomfortable to be under such close scrutiny. Disclosure does not come easily to everyone and there may be occasions when some invisible but significant line may be unhelpfully crossed.

We build relationships through the quality of presence. For those who are in Christian ministry, the supervisory relationship is determined by both the presence of God and the presence of human encounters, both with self and others. Meaningful presence is determined by effective boundaries, which are themselves reliant on the wise use of power. Thus the issue of power within pastoral supervision needs to be reflected upon to ensure that neither the presence of the Divine, nor the presence of each participant, nor the dynamics of the group itself, is clouded or contaminated.

\section{Power in the pastoral supervisory relationship}

An understanding of power in the pastoral supervisory relationship is 'better explored than ignored,', ${ }^{27}$ because, as put bluntly by Morgan,'Power influences who gets what, when and how.'28 Power can be defined simply as 'the medium through which conflicts of interest are ultimately resolved'. ${ }^{29}$ I propose that the quality of presence may be helpfully established or contaminated by the use or misuse of power, a link which I seek to clarify here.

This ever-present yet mostly invisible element, termed 'power', needs to be understood and acknowledged for successful pastoral supervision to take place. The role of the supervisor, and his or her understanding and use of power, is essential to developing the most helpful interaction. The use of power modelled within pastoral supervision may well impact the way the minister uses power within the Church. 'Powerlessness ... tends to breed bossiness rather than true leadership. In large organizations ... it is powerlessness that often creates ineffective desultory management and petty, dictatorial, rulesminded managerial styles. ${ }^{\prime 30}$ Benefiel and Holton advocate that 'the goal [in supervision] is always critical reflection and professional growth, not power or 
control. The problem with power and control in the supervisory relationship, as elsewhere, is that it does not circulate; it tends to accumulate, to become increasingly asymmetric.' ${ }^{31}$ In light of these difficulties, how can power be exercised properly, especially within pastoral supervision for the purpose of ministerial growth and accountability?

Power in the Church is an interesting and sometimes confusing concept. We seek and trust in the power of God (Eph 6:10-11). We are living in the age of the Spirit, whose power draws out and leads to the completion of what Jesus began (Acts 1:8; Jn 14:25-26). In relation to power, the New Testament writings identify a set of functions for the oversight of the first Christian congregations as the new covenant community:

Bishops were to 'take care of God's church' (1 Tim. 3:5); deacons were those who served (1 Tim. 3:13); and elders whom Paul had earlier called 'overseers', whose duty it was 'to shepherd the church of God' (Acts 20:28) were to exercise 'rule' over others (I Tim. 5:17), though precautions were urged that they should 'tend the flock of God ... exercising the oversight ... with humility' (I Pet 5:2-5). ${ }^{32}$

However, 'power can often be considered a dirty word in church circles', state Leach and Paterson. 'A proper emphasis on servanthood in ministry can easily be confused with a refusal to name and exercise properly the power that the authorisation of the church confers and with which charismatic gifts are invested. ${ }^{33}$ Christian leaders have power, both divine and human, which is used in and through the church and the community of faith. A discerning spirit, and great wisdom, is required to know when to exercise power over others and when to empower; when to exercise God-given authority and when to make room for the power of God to move and inspire other individuals, groups and the community.

The notion of 'authority' is therefore inherent in the concept of power and its use. The common perception of authority is that it belongs to a person who has been given power to make and enforce decisions. It can also refer to someone who is an expert (authority) in a field (eg supervision). A clear understanding of the authority/power dynamic is crucial, because it affects the way pastoral supervision is offered and the ways in which those involved will relate to each other. In order to arrive at a greater understanding of the dynamics of power within the pastoral supervisory relationship, it is helpful to consider the five types of power identified by French and Raven: reward, 
coercive, legitimate, expert and referent. ${ }^{34}$ Johnston gives a succinct definition of these types of power, the first four of which he explains here:

Briefly, reward power is evident when the person with power has the capacity to offer a reward or benefit to the one they seek to influence. Coercive power exists when, rather than reward, punishment can be inflicted for failure to comply. Legitimate power involves situations in which a person believes that the one with power has a recognised right to exercise authority by virtue of the number of things including but not limited to cultural conditioning and social or organizational structures ... Expert power is grounded in knowledge, experience or ability that a particular person may have or have access to which is needed by others. ${ }^{35}$

It is evident, from above, that some of these forms of power will not be helpful within a supervisory context, and that power needs to be wisely used. Manipulative, enforced or dominant power can negatively affect the pastoral supervisory relationship. The fifth type of power, referent power, which can be defined as the ability of a leader to cultivate the respect and admiration of his followers and lead by example, ${ }^{36}$ is a helpful use of power in the supervision process.

Supervision provides the opportunity for the expert power of the supervisor to develop referent power within the supervisee/s: 'Referent power is not coercive or rewarding in nature, rather it is by virtue of the strength of association that power is transferred from one to another. ${ }^{\prime 37}$ Furthermore, Johnston proposes this 'referent power ... could well lead to the exercise of a more healthy power within the wider church context, which in turn can impact community at large. ${ }^{38}$

Alongside human power, divine power also needs to be recognised in the pastoral supervision encounter. Pastoral supervision within a ministerial context holds at its centre the belief that God is present, and ultimately holds the power, directs the activities, inspires the mind and heart, and brings about change. 'For where two or three gather in my name, there am I with them' (Mt 18:20). One respondent remarked, 'The Power of God gives someone the courage to share, listen and respond appropriately to a pastoral situation. There can be a kind of "energy transfer" between people who are keenly in tune with God and one another.' 
Respondents to the questionnaire identified that 'the power of God always enhances and develops the supervisory relationship' and that God is 'the source, the driver, the power of change and progress'. They used words such as 'energy' and 'enablement' to describe this power: the 'strength that comes from the Presence of God's Spirit'. One respondent stated, 'Sometimes the Power of God's Spirit confirms what we already know and what we should do.' Perhaps Brueggemann is following a similar thought when he states, 'Theological reflection is the training of the imagination so that we are freed to discern the Spirit and to let the Scripture, in all its maddening obscurity as well as glory, lead us where it will.'39 He goes on to say that the Bible provides us with 'an alternative identity, an alternative way of understanding ourselves, an alternative way of relating to the world. It offers a radical and uncompromising challenge to our ordinary ways of self-understanding. 40

The book of Hebrews declares, 'the word of God is alive and active. Sharper than any double-edged sword, it penetrates even to dividing soul and spirit, joints and marrow; it judges the thoughts and attitudes of the heart' (Heb 4:12). For those who are of like mind and spirit the use of Scripture can strongly inform attitudes, convictions and decisions and be a persuasive power in the transformational thinking.

Even with Christian leaders who seek to follow God, power dynamics introduce challenges and opportunities with regard to perceived and actual power. "Power operates in the "in-between" spaces in contexts and relationships. Just as a leader cannot lead without followers, individuals and groups cannot exercise power independent of context and relationships.'41 Johnston notes, 'the interactions within the group influence the resultant contribution of each member. ${ }^{\prime 2}$ Part of the role of the supervisor is 'to monitor and facilitate the development of the group and the way it relates, in particular this involves attention to power dynamics and group plot'.43 'Groups do not happen. They are all created and nurtured,' says Bolton. ${ }^{44}$ The task at hand and the desired outcome should direct and influence the nature of presence and the practice of power. If there is an unwillingness to be present or no sense of spiritual encounter, or misplaced or misused power, by any in the supervisory relationship, it will undermine the essential elements of a sacred and safe space for all.

The issue of power naturally raises the issue of vulnerability. One respondent commented, 'Opening oneself to others makes one vulnerable. As human beings we are sometimes slow to do this - to give others "power" over us.' 
Another respondent wanted to acknowledge 'the power of certain individuals due to their role/seniority in the church, and how this had potential to negatively influence the supervisory relationships.' For instance, a person's role might influence where a minister might be appointed in the future. Despite attempts to mitigate these concerns, it was mentioned that they were 'still lingering'. This raises the question as to whether a person who holds a position of authority over the supervisee/s can effectively fulfil the task of a pastoral supervisor, or whether there is a danger that the person's role could potentially obstruct or distort the supervisory relationship (and/or the group process).

Leach and Paterson emphasise that the team leader needs to be alert to the complexity of the dynamics of their own power. ${ }^{45}$ The supervisor has the power to use or not to use his or her power as best suits the needs of the supervisee/s at that particular time in that particular context. Some sense of this is perhaps reflected in one respondent's comment: 'The power of the District Superintendent being the same as everyone else in the room as a nonenforcing presence of human power has great potential.'

Spoelstra and Pienaar state that 'only the strong can afford to be weak ... in fact, the strong, by being weak become even stronger. ${ }^{46}$ I suggest that an effective pastoral supervisor needs to embrace this 'weak power', which at times Jesus modelled, in order to create safety and space for their supervisees to experience self-examination and pastoral encounter. 'The Pastoral Supervisor is therefore always a powerful person and needs to be aware of that power and use it for good.' 47

However, power is not only an aspect of the authority attached to the position of an individual but can also be inherent in the nature and behaviour of any participant in pastoral supervision. Certain people hold more power because of their personality. Indeed, one person can have power over another even though their roles may be equal. This is important for the pastoral supervisor to recognise, since

to be trusted with the story of another is to be given power. The more honest and vulnerable a person is encouraged to be, the more powerful will be the interventions we make and the more important it becomes that we are in touch with what the Holy Spirit is doing and with the dimensions of our own personalities and experiences that are likely to get in the way. ${ }^{48}$ 
To summarise, pastoral supervision raises the issue of power, especially where one of the individuals in the supervisory context holds a role of authority. Miller and Rollnick recommend a style which allows the supervisor to meet his or her professional responsibilities and at the same time create the space for supervisees to grow, learn and develop their unique ways of knowing and engaging within a range of work settings. ${ }^{49}$ What can make the supervisory relationship safer is the naming of power issues and, where necessary, clarifying dual roles. The supervisor needs to be explicit if it is necessary to evoke legitimate power within the situation. This covenant relationship, which we will discuss in a later section, enables the issue of power to be transparent. This leads us, therefore, to consider the important notion of boundaries in pastoral supervision.

\section{Boundaries: the intrinsic link of presence and power}

Whenever one is in the presence of another, power dynamics exist, and establishing and upholding mutually respectful boundaries is core to creating meaningful presence. A safe, secure and compassionate experience of the presence of the other, inviting the presence of God, is needed within pastoral supervision in order to enable being present to oneself - the opening of one's 'inner gate', not only to one's inner thoughts, but also to one's bodily reactions, emotions, anxieties, dreams, intuitions and vulnerabilities.

For such a level of safety to exist in the pastoral supervision relationship, clear boundaries are required. Ministers, like all human beings, are likely to cross boundaries inadvertently, even though being well intentioned. For instance, we are prone to telling others what they 'should' do or think and we attempt to assert power over the person's internal processing, rather than create the listening presence for the other person to hear their own wisdom. Issues of damaged boundaries are invariably linked to power being wielded inappropriately:

A helpful analogy in this regard is one's own skin - a flexible membrane that both protects one from infection and damage and contains that which is within. Without the boundary of our skin there would not be adequate containment for us or for others. It is interesting to note that when we cross the boundaries of appropriate social conduct, our metaphors of speech relate closely 
to that of breaking the boundary of skin; we refer to a person 'being abrasive', of 'feeling wounded' or 'scarred'. 50

Appropriate boundaries are essential for the healthy functioning of the supervisory relationship, but when issues of power arise, helpful boundaries are at risk of being breached. The pastoral supervisor must encourage respectful boundaries, which keep all concerned adequately contained, for the benefit of the supervisory process and the supervisees. When all concerned in pastoral supervision are committed to holding such boundaries, the personal power of each individual is released. However, when one party ignores boundary needs, then both the safety of the relationship, and of the supervisee's personal power to create the change needed for self, are at risk. Personal power can be seen as the power to navigate one's emotional faculties in order to respond helpfully, rather than react, in all forms of communication. This personal power is the by-product of practising healthy boundaries, of knowing what is 'me' and 'my stuff' and what is not - what is 'you' and 'your stuff' - while remaining committed to the supervisory task at hand. When we empower others by practising healthy boundaries, we ourselves become empowered to be part of meaningful change. A description of such effectively boundaried space that allows for personal reflection and growth is captured in the 1 Corinthians 13 passage on love. We can easily give a nod to the wise counsel of this Scripture without reflecting on its pertinence in our own relationships. Within pastoral supervision, do we traverse boundaries by hurrying in with our solutions, or do we offer patience and love for the other to take as long as they need to 'hear themselves think' through the challenges they face? 'Love is not proud' - but do we 'dishonour' when we arrogantly propose solutions? Do we 'protect' the other person's reality? Do we 'trust' that the other will find their own path, when we compassionately and patiently listen without judgement? Whether in one-to-one or group supervision, the effective pastoral supervisor holds the boundaries, or at least ensures their immediate repair if breached, to retain the sacredness of this listening space.

Proverbs 25:28 states, 'Like a city whose walls are broken through is a person who lacks self-control.' The pastoral supervision covenant is an agreement to uphold helpful boundaries to ensure each person's emotional containment, which is essential for psychological well-being. An effectively boundaried supervisory space enables the supervisor and supervisees to'stay in their own psychological skin' and not invade or damage the space and integrity of the other. By keeping within one's own boundaries, one is able to see the other 
person's perspective, recognise one's own perspective (how life is within my skin) and leave the other free, yet supported, to make the choices they need to make for themselves. In this lies the power of pastoral supervision.

Kadushin emphasises that

the supervisor must accept, without defensiveness or apology, the authority and related power inherent in his [or her] position. Use of authority may sometimes be unavoidable. The supervisor can increase its effectiveness if he [or she] feels, and can communicate, a conviction in his [or her] behaviour. ${ }^{51}$

Pastoral supervision is a mutually respectful, collaborative approach, between supervisor and supervisee. However, within this setting there is no such thing as 'complete confidentiality'. If within the supervisory relationship something is disclosed that is unlawful, or of a nature that requires reporting, the supervisor is obliged to report such details, ideally in collaboration with the supervisee. The issue of confidentiality needs to be detailed in the working agreement before supervision begins.

The feedback from research respondents and relevant literature convinces me that pastoral supervision is a helpful practice, where the expert power is used to develop referent power. It provides a suitable and effective means of supporting leaders in ministry and establishes a way of interacting that encourages deeper listening skills, which leads to deeper respect, deeper understanding and greater self-discovery. This process invites the presence of God and evokes that presence to self and to others.

\section{Implications}

Despite the possibilities that supervision offers, or perhaps because of them, there has often been, in my experience, a resistance to the idea that ministers could significantly benefit from participating in pastoral supervision. Many think that it is intended only for those new into the ministry, or that attending pastoral supervision is a sign of weakness: that self-exposure will minimise their status and reveal their vulnerabilities. Others are concerned that, because of the confidential nature of their work, they cannot reveal or share, either about others or about themselves. Unless the pastoral supervisory space is proven to be safe and beneficial, those who are suspicious and guarded about a supervisory process that is unfamiliar to them will hesitate to venture in. 
Feedback from the respondents in my research illustrates that the implications of power and presence need to be recognised and addressed, in order to create a safe, transformational, sacred space within the pastoral supervisory relationship. It is envisaged that as some ministers share their experience of the blessing of effective pastoral supervision, those who are reticent are likely to reconsider their viewpoint. The means of achieving this objective are varied but essential if pastoral supervision is to be successful. I propose that they include:

- A positive personal conviction of the need to participate in pastoral supervision.

- A commitment to a covenant relationship of quality.

- An appreciation of the vital role of the pastoral supervisor.

\section{The importance of personal conviction}

When one considers attendance of pastoral supervision, the issue of whether attendance was instigated by personal conviction or by the mandatory requirement of an institution (ie, in this case, the Church) has interesting implications. Personal arrangement gives one the opportunity to be voluntarily involved, to choose one's own pastoral supervisor or supervisory group, to influence the agenda and to hold one's own sense of personal power. By contrast, the institutional requirement of supervision is frequently identified whether justifiably or not - with mentoring or line management. Such supervision often has the institution's needs for productivity, control and outcomes at its centre and is often guided towards those ends. While these goals are necessary for the successful running of an institution they often fail to meet the deeper personal needs of those being supervised.

I contend that there is need for pastoral supervision in the Church that attends to those personal needs, because if the minister does not have the support he or she requires, he or she may be prone to burnout or disillusionment, leading to ineffective work, potentially creating more conflict issues within the community and greater risk of health challenges that would impact productivity or could even lead to resignation. The needs of the institution are better served when its members have the professional support that can contribute towards their self-motivation and commitment, empowering them towards achieving their desired goals, including their personal well-being. Thus, 
the Church ought to be actively promoting and financially supporting ministers to receive pastoral supervision, while also giving them a degree of flexibility in choosing how it might take place.

\section{Commitment to covenant relationship}

To achieve the balance of power that is required for the delicate and yet potent work of pastoral supervision, the creation of a supervisory covenant is essential. Such a covenant is similar but not identical to a contract. According to Pyle and Seal, covenants and contracts have common elements, but also significant differences:

Contracts are based on responsibility; covenants are based on relationships. Contracts define boundaries and bind, covenants provide for growth and becoming. Contracts are legalistic and enforceable; covenants focus on accountability and redemption ... covenant is intentional. It grows out of our relationship with God. God's covenant with us colours and shapes our understanding of our covenanting with each other. It provides structure for relationships, with God and others. ${ }^{52}$

In biblical terms and in Christian practice the term 'covenant' is used to describe a mutual agreement of structure and accountability. Pastoral supervision, according to Pohly, affirms the relational nature of the covenant between God and people, which has as its objective, 'the well-being and mission of an entire nation. 53

This covenant relationship that exists between God and self enables those in Christian service to exercise the same covenantal relationship with each other. Hawkins and Shohet state:

Supervision is a joint endeavour in which a practitioner [minister], with the help of a supervisor, attends to their clients [parishioners], themselves as part of their client practitioner [parishioner-minister] relationships and the wider systemic context, and by so doing improves the quality of their work, transforms their client [pastoral] relationships, continuously develops themselves, their practice and the wider profession. ${ }^{54}$ 
The supervisory covenant creates the context and purpose for pastoral supervision, explores the goals of this 'pilgrimage' and consensually determines how it is managed.

In the Methodist Church in Britain's Supervision Policy, it states that the 'Methodist model of supervision ... be an expression of our covenant relationship with the Conference'. The aims of supervision are normative, formative and restorative, and they are 'to ensure that the vocation and work of the minister is valued and nurtured and ensure that health and well-being issues for ministers are addressed. 55

However, attending to the supervision covenant is not simply an institutional responsibility, but also demands an explicit personal responsibility. This ensures that the framework of health and well-being which is being nurtured through pastoral supervision is personal to the minister.

\section{The vital role of the pastoral supervisor}

The professionalism, training and insightful skills of the pastoral supervisor are essential to the effectiveness of the supervisory process. Leach and Paterson remind us that 'to sit with someone as their supervisor is to be in a position of power ... Awareness of the power you have and how to use it for the good of those you work with is an essential dimension of all Christian practices.56 Unless the supervisor gives attention to creating referent power, thus facilitating a meaningful presence to self, to group and to God's Spirit, the much-needed benefits of pastoral supervision are unlikely to be achieved. Hawthorne asserts that there may be times when the supervisor abdicates or manipulates power. She states: 'With the role of supervisor comes the responsibility to be aware of your own power and learn ways of utilising this power in ways that are: appropriate, well intentioned, anti-oppressive and sensitive to the particular background of the supervisee. ${ }^{.57}$

The effective pastoral supervisor has an awareness of how crossing boundaries and mishandling power affects the sense of presence in the supervisory relationship, obstructing or contaminating the potential work of the supervisees. As Benefiel and Holton state, 'supervision is always alert to the issues of equality, to the call to respect deep democracy and its many voices, to be open to change in perspectives.58 The supervisor, in order to effect greater presence to self, to others and to the issue at hand, requires the ability to recognise and call to attention those thought patterns that are blocking progress: 'Supervisors are 
challenged to enhance the quality and depth of the supervisory conversation by making the questioning of assumptions a contextual necessity.59

While there is discussion regarding the inherent, asymmetrical power balance in the pastoral supervisory space, it could be helpful to further explore whether this issue with power has less to do with the tasks of supervision and more to do with the attitude and skill of the supervisor. As observed by Weld:

Key to enabling the transformative function in supervision is the supervisory relationship, which should be built on a foundation of openness and honesty, providing a working partnership that models respect, care, empathy, careful use of humour, challenge and holistic recognition of the worker as a professional being. ${ }^{60}$

It is important to note that the work of an effective pastoral supervisor is in itself challenging and that it should be required of the supervisor also to be receiving supervision, as advocated by Leach and Paterson. ${ }^{61}$ Supervisors themselves require a reflective space to ensure that the crucial elements of presence and power are understood and effectively managed, in order to create a pastoral supervisory process that generates a healthy, transformative, reflective space for others.

\section{Conclusion}

Daniel Sherman asks the question:

Where does a pastor go when he is discouraged, when he is burned out, or when he is facing challenges in his congregation? If he turns to his church leaders he risks sharing information that is very personal and perhaps hurtful. If he tells people in his congregation, it may be misunderstood or even used as a weapon against the pastor. So where can he or she go? Where does a pastor go when the church or congregation is the problem $?^{62}$

This article has shown that professional pastoral supervision is an essential and beneficial practice for those in ministry and for the wider Church. It is an area that needs to be developed and 'normalised' in the lives of those who respond to this vocation.

I propose that training of pastoral supervisors needs not only to include the skillset required but also to explore the issues of power in creating a mutually 
respectful presence and sacred space. This way of being present to ourselves and to the other is only possible when we shift our mindset, including the language we use, from one of hierarchy to one of collaboration.

This collaborative approach is endorsed by Benefiel, who identifies the need of an organisation to provide an environment where there is congruence between work and our moral/ethical values and family responsibilities, in which everyone is treated justly:

people can find meaning, significance and success through work, and where personal and workplace values align to greater outward harmony and inner spiritual life ... to grow holistically and build relationships themselves while they are serving. ${ }^{63}$

She also notes that when these factors are in place it 'improves care'. Christian care, by its nature, is to bear one another's burdens, give preference to one another in honour and do good to all people. In the name of Christ, in ministry and mission, we love one another and build one another up (Gal 6:2; Rom 12:10; Gal 6:10; 1 Thess 5:11).

To achieve this vital improvement, the various aspects that determine effective pastoral supervision, including presence and power, require adequate reflection. Such reflection is imperative to creating a safe, open, authentic and trusting environment within the pastoral supervisory relationship, which in turn has the potential to impact the ministers' personal well-being and their greater sphere of influence, including family, church and community. Pastoral supervision also creates an awareness of the importance of maintaining healthy boundaries, which help each person to navigate the issues of power and presence successfully.

Pastoral supervision not only improves one's quality of work, but also enables the supervisee to reflect on how to create balance, as different boundaries are negotiated. This healthy balance attends to the time given to relationship with parishioners, colleagues, family and friends, as well as to other aspects such as professional and private life; it also attends to the boundaries between home and ministry, and the balance between administrative tasks, ministry, pastoral duties, study and personal well-being. Balance created through pastoral supervision includes the creation of time and space for one's own spirituality, connecting the supervisee with Divine presence and power, which in turn empowers healthy ministry within the people of God. 


\section{Appendix}

\section{QUESTIONNAIRE}

This research questionnaire is intended to explore, record, analyse and attempt to draw conclusions regarding the significance of Presence and Power within the Supervisory Relationship.

Please answer the following questions, bearing in mind your thoughts and experiences when you first engaged in Group Supervision, and having now experienced Supervision.

Please answer the following questions. It should take about 40 minutes and there are 10 questions. The information will be used to compile an evaluation on these elements of Supervision and the results will be used in an article on this subject.

Your views are an important part of this exploration, and as such your honest opinions are valuable.

Each question should be limited to a maximum of 200 words.

\section{A. The Effect of 'Presence' in the Supervisory Relationship}

A1. What do you understand by the term 'Presence' in Supervision? (Give as many understandings of 'Presence' as possible.)

A2. Having defined your understanding of 'Presence', what are some of the elements of 'Presence' that you have recognised in Group Supervision?

A3. In what ways do these elements of 'Presence', that you have identified in question $\mathrm{A} 2$, enhance and develop the Supervisory Relationship?

A4. In what ways do these elements of 'Presence', that you have identified in question A2, distract or obstruct the Supervisory Relationship?

A5. Any other comments/suggestions about the issue of 'Presence' that you would like to offer? 


\section{B. The Effect of 'Power' in the Supervisory Relationship}

B1. What do you understand by the term 'Power' in Supervision? (Give as many understandings of 'Power' as possible.)

B2. Having defined your understanding of 'Power', what are some of the elements of 'Power' that you have recognised in Group Supervision?

B3. In what ways do these elements of 'Power', that you have identified in question B2, enhance and develop the Supervisory Relationship?

B4. In what ways do these elements of 'Power', that you have identified in question B2, distract or obstruct the Supervisory Relationship?

B5. Any other comments, suggestions about the issue of 'Power' within Supervision that you would like to offer?

\section{Notes}

1. Vitello 2010.

2. Sherman 2010.

3. Hawkins and Shohet 2012, p. 5.

4. Association of Pastoral Supervisors and Educators (APSE) 2015.

5. Reflective Practice 2013.

6. Rogers 1961, p. 33.

7. Feinberg 1968, p. 46.

8. Pohly 1993, p. 2.

9. Carroll 2007, p. 34.

10. Pohly 1993, p. 9.

11. Methodist Church in Britain 2013-15, p. 41.

12. APSE 2015.

13. APSE 2015.

14. Miller and Rollnick 2013, p. 15; Page and Wosket 2001, p. 103.

15. Holton 2010, p. 197.

16. Benefiel and Holton 2010, pp. viii-ix.

17. Pohly 1993, p. 10.

18. Thompson 2008, p. 27.

19. Kline 1999, p. 31.

20. Davys and Beddoe 2010, p. 239.

21. Silsbee 2008, p. 21.

22. Brueggemann 2001, p. 10.

23. Ballard 2011, p. 38. 
24. Ballard 2011, p. 38.

25. Schillerbeeckx 1963, p. 15.

26. Ballard 2011, p. 45.

27. Hawkins and Shohet 2012, p. 122.

28. Morgan 1997, p. 170.

29. Morgan 1997, p. 170.

30. Kanter 2001, p. 343.

31. Benefiel and Holton 2010, p. 138.

32. Pohly 1993, p. 10.

33. Leach and Paterson 2010, p. 138.

34. French and Raven 2001, p. 321.

35. Johnston 2004, p. 11.

36. Study.com 2016.

37. Johnston 2004, p. 11.

38. Johnston 2004, p. 16.

39. Brueggemann 2001, p. 37.

40. Brueggemann 2001, p. 10.

41. McGraw Hill Small Group Communications.

42. Johnston 2004, p. 87.

43. Leach and Paterson 2010, p. 163.

44. Bolton 2005, p. 204.

45. Leach and Paterson 2010, p. 164.

46. Spoelstra and Pienaar 1999, p. 131.

47. Leach and Paterson 2010, p. 138.

48. Leach and Paterson 2010, p. 138.

49. Miller and Rollnick 2013, p. 5.

50. Mullally 2016.

51. Kadushin 1992, p. 112.

52. Pyle and Seal 1995, p. 50.

53. Pohly 1993, p. 10.

54. Hawkins and Shohet 2012, p. 5.

55. Methodist Church in Britain 2015.

56. Leach and Paterson 2010, p. 4.

57. Hawthorne 1975, p. 179.

58. Benefiel and Holton 2010, p. 138.

59. Benefiel and Holton 2010, p. 138.

60. Weld 2012, p. 130.

61. Leach and Paterson 2010, p. 164.

62. Sherman 2010.

63. Benefiel 2005, p. 150.

\section{Bibliography}

Ballard, P. 2011. 'The Bible in Theological Reflection: Indications from the History of Scripture', Practical Theology 41: 35-47. 
Benefiel, M. 2005. Soul at Work: Spiritual Leadership in Organisations. New York: Seabury Books.

Benefiel, M. and Holton, G. 2010. The Soul of Supervision. New York: Moorehouse Publishing.

Bochen, C. M. 2000. Thomas Merton: Essential Writings. New York: Orbis Books.

Bolton, G. 2005. Reflective Practice: Writing and Professional Development. 2nd edn, London: Sage.

Boyatzis, R. and McKee, A. 2005. Resonant Leadership. Boston, MA: Harvard Business School Press.

Brueggemann, W. 2001. The Bible Makes Sense. Louisville, KY: Westminster John Knox Press.

Caroll, M. 2007. 'One More Time: What is Supervision?', Psychotherapy in Australia 133: 34-40.

Davys, A. and Beddoe, L. 2010. Best Practice in Professional Supervision. London: Jessica Kingsley.

de Gruchy, J. 1966. Theology and Ministry in Context and Crisis. New York: Harper \& Row Publishers.

Feinberg, J. 1968. Reason and Responsibility: Readings in Some Basic Problems of Philosophy. Belmont, CA: Dickenson Publishing.

French, J. R. P. and Raven, J. 'The Bases of Social Power', in Shafritz, J. M. and Ott, J. S. (eds). 2001. Classics of Organization Theory. 5th edn, Orlando, FL: Harcourt College Publishers.

Hawkins, P. and Shohet, R. 2012. Supervision in the Helping Professions. 4th edn, Maidenhead: Open University Press.

Hawthorne, L. 1975. 'Games Supervisors Play', Social Work Journal 203: 179-83.

Holton, G. 'Wisdom's Garden: A Metaphor for Cross-Professional Supervision Training', in Benefiel, M. and Holton, G. (eds). 2010. The Soul of Supervision: Integrating Practice and Theory. New York: Morehouse Publishing.

Johnston, R. 2004. 'The Relevance of Non-Directive Consultancy for Contemporary Church Ministry', unpublished MA dissertation. University of Sheffield at Cliff College.

Kadushin, A. 1992. Supervision in Social Work. 3rd edn, New York: Columbia University Press.

Kanter, R. M. 'Power Failure in Management Circuits', in Shafritz, J. M. and Ott, J. S. (eds). 2001. Classics of Organization Theory. 5th edn, Orlando, FL: Harcourt College Publishers.

Kline, N. 1999. Time to Think: Listening to Ignite the Human Mind. London: Cassell.

Leach, J. and Paterson, M. 2010. Pastoral Supervision: A Handbook. London: SCM Press.

Miller, W. R. and Rollnick, S. 2013. Motivational Interviewing: Helping People Change. New York: Guilford Press.

Morgan, G. 1997. Images of Organization. 2nd edn, Thousand Oaks, CA: Sage Publications.

The NIV Study Bible: New International Version. 1985. Grand Rapids, MI: Zondervan.

Page, S. and Wosket, V. 2001. Supervising the Counsellor: A Cyclical Model. 2nd edn, London: Routledge. 
Pohly, K. 1993. Transforming the Rough Places: The Ministry of Supervision. Dayton, OH: Whaleprints.

Pyle, W. and Seal, M. 1995. Experiencing Ministry Supervision: A Field-Based Approach. Nashville, TN: Broadman \& Holman Publishers.

Rogers, C. 1961. On Becoming a Person: A Therapist's View of Psychotherapy. London: Constable.

Rohr, R. 2013. Yes, and ...: Daily Meditations. Cincinnati, OH: Franciscan Media.

Schillerbeeckx, E. 1963. Christ: The Sacrament of the Encounter with God. London: Sheed \&Ward.

Silsbee, D. 2008. Presence-Based Coaching: Cultivating Self/Generative Leaders through Mind, Body and Heart. San Francisco, CA: Jossey-Bass.

Spoelstra, H. I. J. and Pienaar, W. D. 1999. Negotiation: Theories, Strategies and Skills. Kenwyn, South Africa: Juta and Co.

Thompson, J. 2008. Theological Reflection. London: SCM Press.

Weld, N. 2012. A Practical Guide to Transformative Supervision for the Helping Professions: Amplifying Insight. London: Jessica Kingsley.

\section{Electronic publications}

Association of Pastoral Supervisors and Educators (APSE). 2015. http://www. pastoralsupervision.org.uk/pastoral-supervision/ (accessed 1 July 2015).

McGraw Hill Small Group Communications site for students. http://www.mhhe.com/ socscience/comm/group/students/power.htm\#ref (accessed 27 June 2015).

Methodist Church in Britain. 2013-15. Courage, Cost and Hope: The Report on the PAST CASES REVIEW. http://www.methodist.org.uk/media/1683823/past-cases-review2013-2015-final.pdf (accessed 20 April 2016).

Methodist Church in Britain Draft Supervision Policy, MC/15/86. 2015. http://www. methodist.org.uk/media/1858466/counc-MC15-86-draft\%20Supervision\%20 Policy-october-2015.pdf (accessed 28 November 2016).

Mullally, V. 2016. 'Relationship Boundaries - Why They Matter'. Koemba Parenting: http://www.koemba.com/forum/relationship-boundaries-why-they-matter/ (accessed December 2016).

Reflective Practice: Formation and Supervision in Ministry. 2013.

http://www.reflective-practice.org/author_guidelines (accessed 20 June 2015).

Sherman, D. 2010. PastorBurnout.com, 'We're here, because we've been there'. http://www.pastorburnout.com/pastor-burnout-statistics.html (accessed 3 July 2015).

Study.com, California. 2016. http://study.com/academy/lesson/referent-power-inleadership-definition-examples-quiz.html (accessed 28 November 2016).

Vitello, P. 2010. 'Taking a Break from the Lord's Work', New York Times, 1 August. http://www.nytimes.com/2010/08/02/nyregion/02burnout.html (accessed 3 July 2015). 